\title{
Rapid Exhumation of High-Pressure Metamorphic Rocks in Kythera-Peloponnese (Greece) Revealed by Apatite (U-Th)/He Thermochronology
}

\author{
Antonios E. Marsellos, ${ }^{1,2, \star}$ Kyoungwon Min, ${ }^{2}$ and David A. Foster ${ }^{2}$ \\ 1. Department of Environment and Technology, University of Brighton, Brighton BN2 4GJ, United Kingdom; \\ 2. Department of Geological Sciences, University of Florida, Gainesville, Florida 32611, USA
}

\begin{abstract}
A B S T R A C T
Apatite (U-Th)/He and apatite fission-track cooling ages from high-pressure (HP) metamorphic rocks in the South Aegean forearc along the Kythera Strait (Kythera and southeastern Peloponnese) suggest rapid exhumation during Middle to Late Miocene times. HP rocks from the Kythera Strait exhibit two perpendicular extensional structures. Samples with arc-normal or arc-parallel extensional fabrics yielded apatite $(\mathrm{U}-\mathrm{Th}) / \mathrm{He}$ cooling ages of $\sim 8-10 \mathrm{Ma}$. The more precise $(\mathrm{U}-\mathrm{Th}) / \mathrm{He}$ ages are consistent with previously reported apatite and zircon fission-track ages obtained from the same rock units. The less precise, but still accurate, fission-track data provided a reference for (U-Th)/He dating on relatively young uranium-poor apatites. The combined data, therefore, precisely and accurately constrain the exhumation history of HP rocks and indicate that localized arc-parallel extension in the Kythera Strait was active for an $\sim 5$ m.yr. interval during the regional arc expansion.
\end{abstract}

\section{Introduction}

Extensional detachment faulting under both ductile and brittle conditions is an important mechanism in bringing high-pressure/low-temperature (HP/LT) metamorphic rocks to the surface (Platt 1986) and commonly occurs above a retreating subducting slab. In the case of the Hellenic subduction zone, thermochronologic studies revealed that exhumation of HP rocks occurred through detachment faulting during the Early to Late Miocene (Thomson et al. 1999; Ring et al. 2001; Brix et al. 2002; Marsellos 2008). The Mediterranean region contains numerous high-pressure (HP) and ultra high-pressure (UHP) metamorphic terranes with variable metamorphic ages, suggesting that the burial-metamorphism-exhumation cycle is a recurring process in subduction settings.

This article presents apatite (U-Th)/He ages from the phyllite-quartzite unit (PQU) metamorphic rocks in order to better constrain the low-temperature (low-T) thermal history for the southwestern section of the Hellenic arc (southern Peloponnese

Manuscript received September 11, 2012; accepted January 30, 2014; electronically published June 5, 2014.

* Author for correspondence; e-mail: marsellos@gmail.com. and Kythera) and sheds light on tectonics associated with arc-parallel extension. This study shows that combining relatively accurate fission-track analyses with higher-precision (U-Th)/He dating increases utility of the low- $T$ thermochronology of uranium-poor apatites. The thermochronologic data- $(\mathrm{U}-\mathrm{Th}) / \mathrm{He}$ and fission track-are combined with structural and fabric relationships in the area to provide temporal constraints on arc-parallel extension in the Kythera Strait, which has significant implications for the Neogene development of the Hellenic arc and the South Aegean subduction system.

Rollback and Associated Arc-Parallel Extension. The Aegean plate overrides the subducting African slab at the Hellenic subduction zone (fig. 1). Initiation of the Aegean forearc began when the first carbonate platforms at the leading edge of Adria arrived at western Greece at $\sim 35 \mathrm{Ma}$ (van Hinsbergen et al. 2005a, 2010). Oligocene to Early Miocene K-Ar ages (Seidel et al. 1982; Jolivet et al. 1996) and numerous Early to Middle Miocene fission-track cooling ages also point to forearc evolution beginning in the Late Oligocene-Early Miocene (e.g., Thomson et al. 1999; 

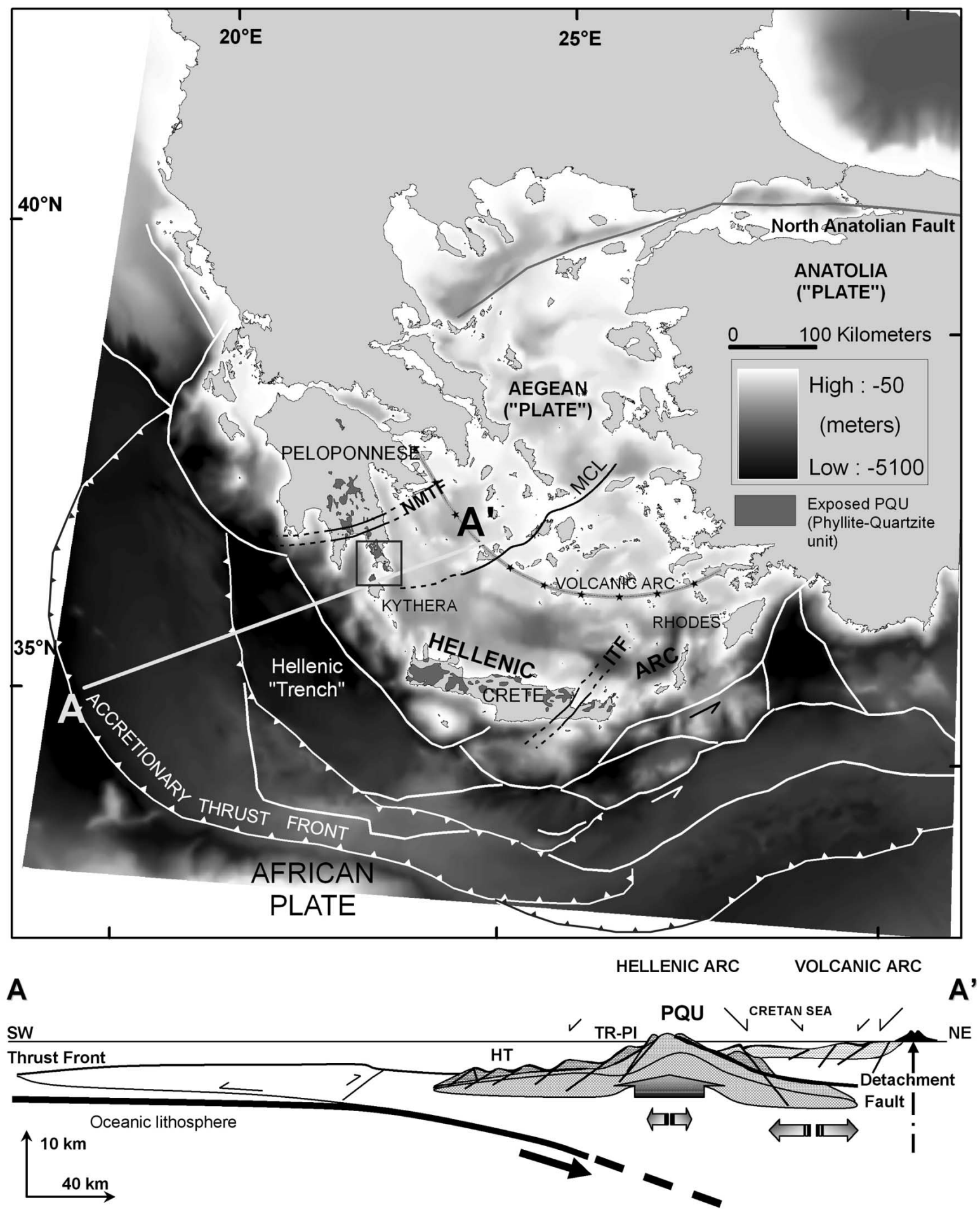

Figure 1. Tectonic setting of the Hellenic arc with a representative cross section (A-A') through the Kythera Strait. See text for details. HT = Hellenic trench, TR-PI = Tripolis-Pindos nappe units above extensional detachment, PQU $=$ phyllite-quartzite unit below extensional detachment, NMTF $=$ North Mani Transverse Fault, ITF $=$ Ierapetra Transverse Fault, MCL = Mid-Cycladic Lineament. 
Brix et al. 2002; Marsellos et al. 2010a). Development of the South Aegean forearc has been attributed to the current subduction configuration, although subduction was ongoing throughout most of the Mesozoic and the entirety of the Cenozoic, during variable convergence rates (Faccenna et al. 2003; Jolivet and Brun 2010). The subduction rate was slower in the Early Miocene (Dewey et al. 1989; Rosenbaum et al. 2004) between Africa and Europe, causing rollback (Royden 1993) and extension since $\sim 35 \mathrm{Ma}$ (van Hinsbergen and Schmid 2012). The extension (e.g., Angelier and Pichon 1980) culminated during 25-16 Ma, as manifested by a series of detachment faults now exposed in the South Aegean (e.g., Lister et al. 1984; Fassoulas et al. 1994; Thomson et al. 1998; Jolivet and Faccenna 2000; Jolivet et al. 2004).

Rollback is commonly followed by arc-backarc extension (especially with an old African subducting slab; Molnar and Atwater 1978; Royden 1993; Jolivet et al. 1994; Lister et al. 2001), arc-parallel extension along the forearc (Marsellos and Kidd 2008), and trench migration (e.g., Dewey 1981; Brun and Faccenna 2008). These processes, in combination with the exhumation of the HP rocks, are reflected by the evolving subduction zone geometry of an amphitheater-shaped basin (Spakman et al. 1988,1993 ) that increases its curvature. About 150 $\mathrm{km}$ of arc-normal extension between 16 and $11 \mathrm{Ma}$ accompanied trench migration, exhumation of HP rocks at either end of the Aegean trench that was primarily controlled by rollback of the subducting slab (Marsellos et al. 2012b). Slab retreat (Royden 1993), successive slab-tearing episodes (e.g., Govers and Wortel 2005; van Hinsbergen 2010; Biryol et al. 2011; Gesret et al. 2011; Salaón et al. 2012) with subsequent differential arc expansion (Marsellos et al. 2010a), and strain localization (Jolivet et al. 2012) have resulted in differential horizontal rotation in the Miocene (Kissel and Laj 1988; Duermeijer et al. 1998; Walcott and White 1998; ten Veen and Kleinspehn 2003; van Hinsbergen et al. 2005b; Bradley et al. 2013).

Rollback and extension provides space allowing rapid exhumation of HP rocks (Platt 1986). This differential rollback along strike of the subduction zone (Marsellos et al. 2010a) is most likely associated with a bending of the arc (e.g., Royden and Husson 2006). Differential rollback rates may cause uneven exhumation along the forearc in the area, whereby peak metamorphic conditions of exhumed rocks are expected to be spatially correlated with rollback rates. The central section of the CretanPeloponnese ridge, which experienced rapid rollback, exposes metamorphic rocks with higher peak pressure-temperature $(P-T)$ conditions (fig. 2) than the metamorphic units in the eastern and western flanks (Seidel et al. 1982; Theye and Seidel 1991, 1993; Theye et al. 1992; Gerolymatos 1994). The spatial relationship of rollback rate, metamorphic grade, and exhumation rate needs to be better defined to understand how subduction geometry evolves in retreating subduction zones such as the Hellenic trench.

\section{Tectonic and Geological Setting}

Hellenic Forearc. The Hellenic forearc ridge contains substantial exposures of the Neogene-Recent accretionary wedge (fig. 1). Pre-Neogene thrust nappes are exposed in the Hellenic forearc ridge and overlie the metamorphosed basement of HP rocks. The large-scale internal structure of the Hellenic forearc ridge developed during the Late EoceneEarly Miocene collision of the Apulia microcontinent (attached to the African plate) as it was subducted beneath and accreted to the active European continental margin (the Pelagonian terrane; Thomson et al. 1998). Miocene marine sediments faulted by extension (Christodoulou 1965; Freyberg 1967; Theodoropoulos 1973; Lyberis et al. 1982) were deposited concurrently with cooling, exhumation, and uplift of the underlying HP rocks, beginning in the Early Miocene in Crete (Fassoulas et al. 1994; Jolivet et al. 1996; Thomson et al. 1999; Brix et al. 2002) and the central Peloponnese and since the Middle-Late Miocene in Kythera and the southeastern Peloponnese (Marsellos et al. 2010a).

PQU and Metamorphism. The sedimentary cover of Apulia is mostly represented by the rocks of the PQU and the Tripolis unit and are exposed over wide areas on the Peloponnese-Cretan ridge, including Kythera Island. There are three lithotectonic units exposed in Kythera. The structurally lower metamorphic unit consists mainly of phyllite and quartzite, with mylonitic marbles and blueschists (Lekkas 1986; Gerolymatos 1994; Marsellos 2006) as well as rare, small occurrences of metagranite and gneiss. The protolith of the metamorphic PQU was a mid-Carboniferous to Triassic rift sequence (Krahl et al. 1983), resulting from the opening of a southern branch of the Neotethyan ocean (Pe-Piper 1982; Seidel et al. 1982; Robertson and Dixon 1984). U-Pb ages of detrital zircons from PQU rocks range from Carboniferous to Archean and show a major pan-African signature; the gneissic lenses show Carboniferous U-Pb ages (Xypolias et al. 2006; Zulauf et al. 2007; Marsellos et al. 2012a). The PQU metasedimentary rocks were underthrusted (Seidel et al. 1982; Bonneau 1984) 


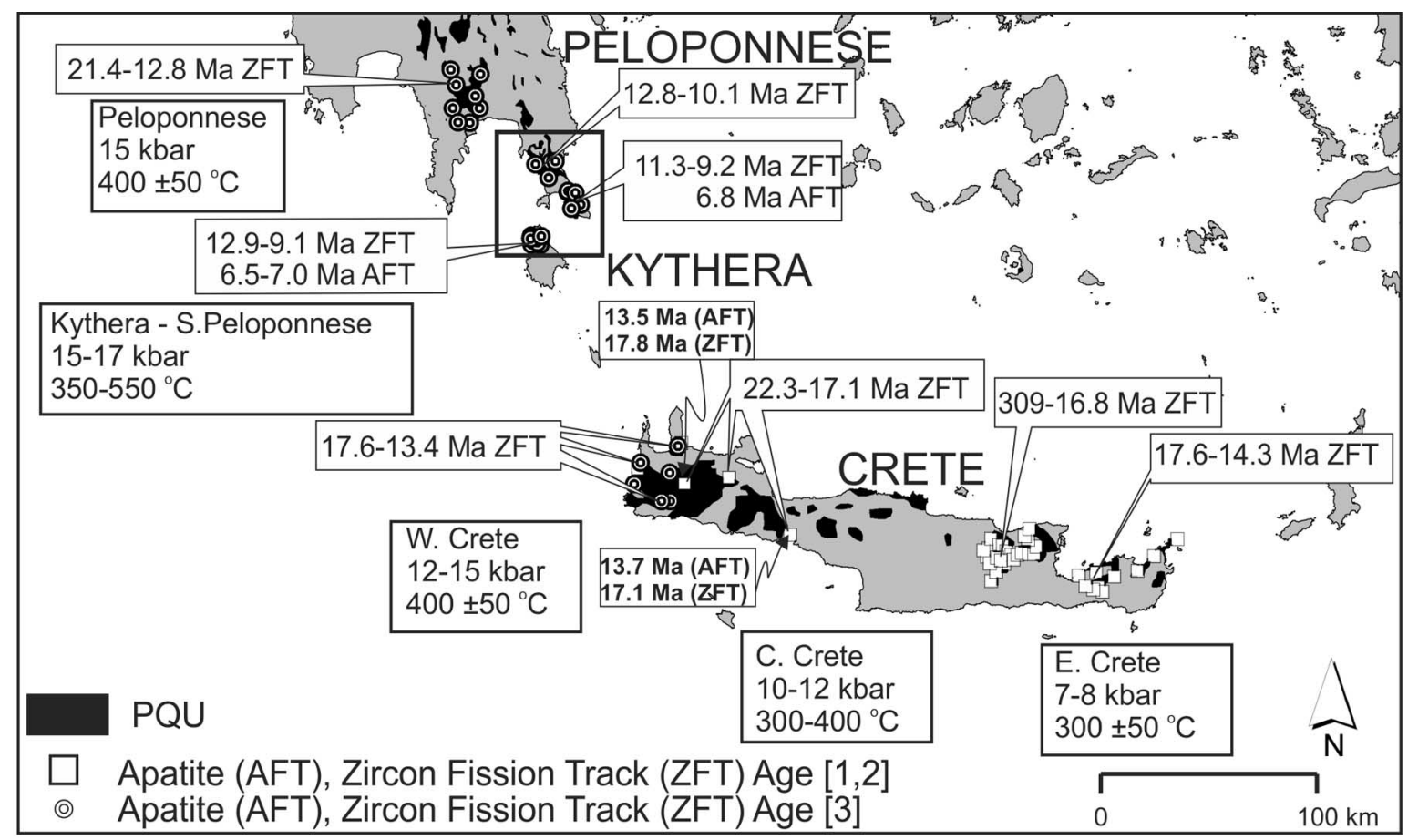

Figure 2. Apatite fission-track (AFT) and zircon fission-track (ZFT) ages in the phyllite-quartzite unit (PQU) of Peloponnese, Kythera, and Crete. Sample localities are shown on the map with open squares referencing ZFT and AFT ages by Brix et al. (2002; [1]) and Thomson et al. (1999; [2]) and with circles referencing ages by Marsellos et al. $\left(2010 a_{;}[3]\right)$. Outlined boxes contain ranges of fission-track ages. The black areas in the map indicate where PQU rocks are exposed on the surface. Pressure-temperature-time data are for the high-pressure/low-temperature rocks of the phyllite-quartzite series in Peloponnese, Kythera, and Crete (after Seidel et al. 1982; Thomson et al. 1998).

and experienced HP/LT metamorphism in the Oligocene to Early Miocene.

The metamorphic $P$-T conditions of the HP rocks along the Hellenic forearc increase from the edges of the forearc toward the Kythera Strait (fig. 2). In Crete, the PQU rocks experienced HP/LT metamorphism under conditions of up to $350^{\circ} \mathrm{C}$ in eastern Crete and $400^{\circ} \pm 50^{\circ} \mathrm{C}$ in western Crete and mostly 8-12 kbar (Seidel et al. 1982; Theye et al. 1992), with isolated occurrences of even higher pressure ( 16 kbar) and similar temperature $\left(<400^{\circ} \mathrm{C}\right)$ in Chania, western Crete (Jolivet et al. 1996). These metamorphic conditions took place between 24 and $19 \mathrm{Ma}$ (Brix et al. 2002). In the Peloponnese, PQU rocks experienced conditions of up to $15 \mathrm{kbar}$ and $450^{\circ} \mathrm{C}$ (Seidel et al. 1982; Theye and Seidel 1991, 1993; Theye et al. 1992). In Kythera PQU, metamorphic mineral assemblages indicate a peak metamorphic pressure of 15-17 kbar and temperatures approaching $550^{\circ} \mathrm{C}$ (Gerolymatos 1994).

In the area of Potamos on the island of Kythera, orthogneiss lenses occur within schists of the PQU
(Petrocheilos 1966; Xypolias et al. 2006), here named "Potamos gneisses." Fault-bound lenses of gneiss intercalated with phyllite (mostly shown as $\mathrm{C}^{\prime}$ structures; Marsellos and Kidd 2008) are relatively common along the entire Cretan-Peloponnese ridge. Mica-schist of the PQU on Kythera show arc-parallel extensional fabrics and zircon fission-track (ZFT) cooling ages of 10-13 Ma related to exhumation coeval with expansion of the arc and subduction rollback. The Potamos gneisses predominantly exhibit arc-normal extensional structures and younger ZFT cooling ages ( 9 Ma; Marsellos et al. 2010a).

Extension and Exhumation at Kythera Strait. During Early to Late Miocene exhumation ( 16-11 Ma), a series of large-displacement extensional detachment faults developed, bringing metamorphic rocks against their nonmetamorphic cover during three stages of extension (Marsellos and Kidd 2008). Highly strained rocks of the PQU on Kythera and the southeastern Peloponnese (Marsellos et al. 2010a) exhibit a substantial change in extension direction during their ductile strain history. Change 


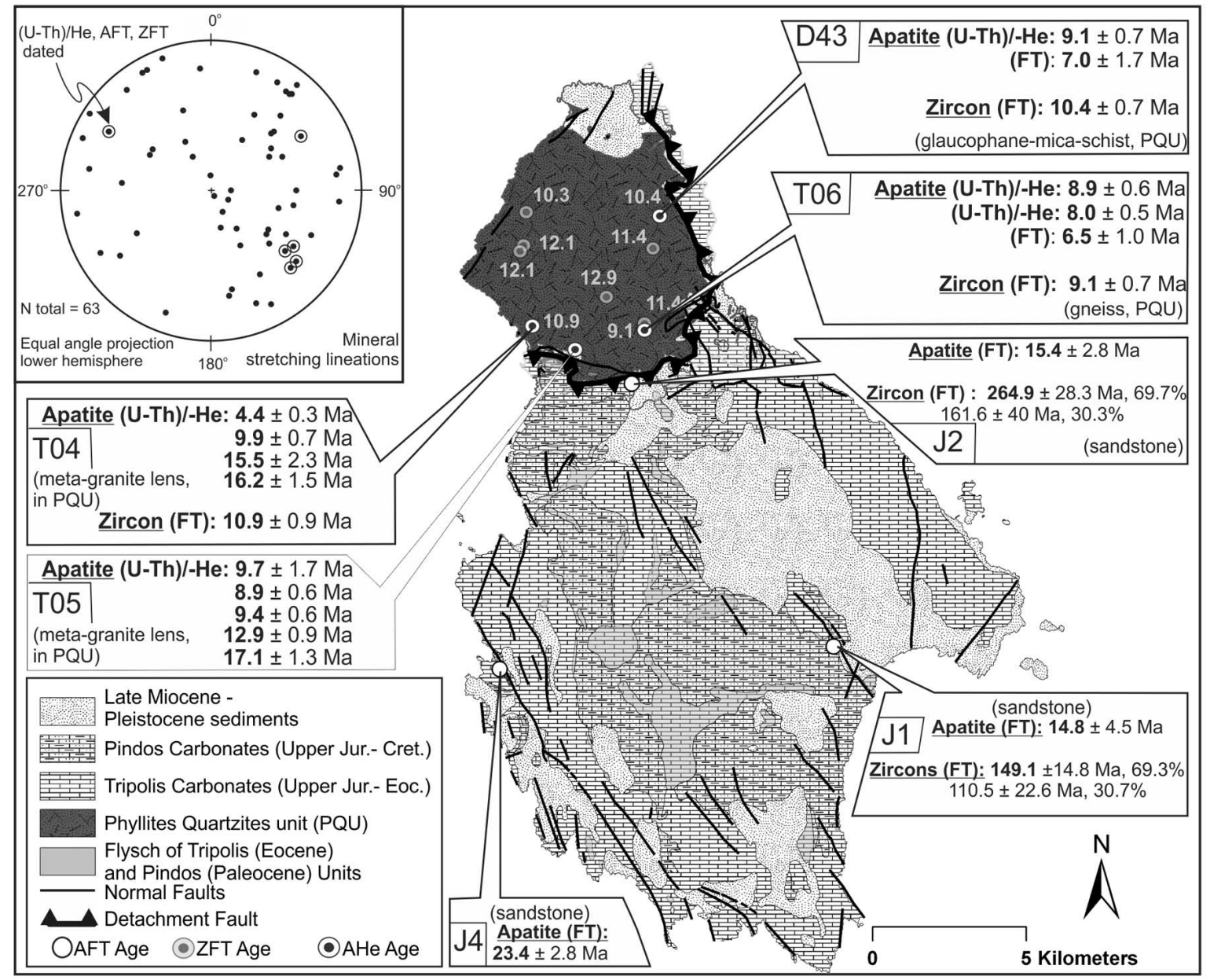

Figure 3. Sample locations of apatite helium (U-Th)/He (AHe), zircon fission-track (ZFT), and apatite fission-track (AFT) cooling ages from below (lower plate, phyllite-quartzite unit [PQU]) and above (upper plate, Tripolis flysch) the detachment on Kythera Island. The new ages (AHe) from lower plate samples are displayed with previously reported ZFT from below and above the detachment and AFT from the upper plate (Marsellos et al. 2010a, 2010b). The geological map was modified after Petrocheilos (1966) and Marsellos et al. (2010b).

of extension has been observed from cooling ages of arc-normal and arc-parallel stretching lineated rocks. The first change occurred at $\sim 16-14 \mathrm{Ma}$, when arc-normal extension was replaced by localized arcparallel extension, while the second change occurred at $\sim 11-9 \mathrm{Ma}$, when arc-normal extension was restored. Fabrics in quartzose lithologies change from arc-parallel, mica-blue amphibole fabrics to arc-normal, kyanite-mica fabrics in Kythera and the southeastern Peloponnese.

The (U-Th)/He cooling ages presented below confirm with higher precision that the latest stage of exhumation of the PQU arc-parallel lineated rocks and gneissic arc-normal lineated rocks occurred at a similar time and with a similar (rapid) exhuma- tion rate, indicating that they were juxtaposed prior to final exhumation.

\section{Analytical Methods}

(U-Th)/He and scanning electron microscope (SEM) analyses were performed at the University of Florida. $(\mathrm{U}-\mathrm{Th}) / \mathrm{He}$ ages were successfully determined for apatite grains from 6 of 19 hand specimens obtained from PQU rocks from Kythera and the Peloponnese along the Hellenic forearc ridge (figs. 3, 4). Outcrop samples were processed following standard mineral separation procedures (Bernet and Garver 2005) of crushing, sieving, magnetic separation, and heavy liquid methods. To avoid apatite 


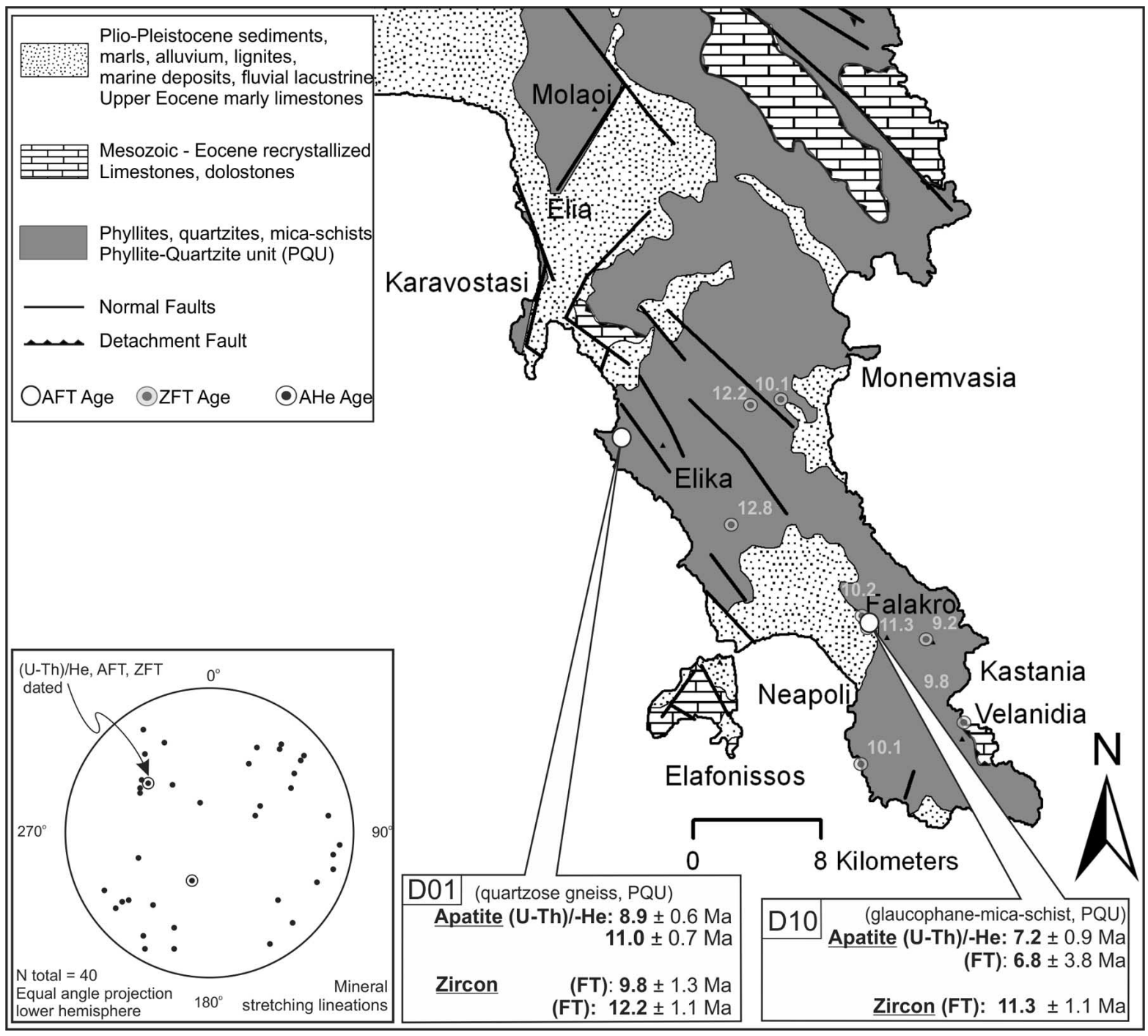

Figure 4. Sample locations of apatite helium (U-Th)/He (AHe), zircon fission-track (ZFT), and apatite fission-track (AFT) cooling ages from below (lower plate, phyllite-quartzite unit [PQU]) the detachment on the Neapoli area, southeastern Peloponnese (western part of the Hellenic forearc). The new ages (AHe) from lower plate samples are shown with ZFT and AFT data from below the detachment (Marsellos et al. 2010a, 2010b). This simplified geological map of southeastern Peloponnese was modified after Bornovas and Rontogianni-Tsiabaou (1983).

grains with any inclusions, we carefully examined the apatite grains under a stereomicroscope with open and cross-polarized conditions at maximum magnification of $\times 160$. Apatite grains with visible inclusions were discarded. However, many grains are not $100 \%$ transparent, hampering identification of fine inclusions; thus, we cannot rule out the possibility of small inclusions in our samples. Selected grains were examined using SEM to confirm their mineral identity and basic morphological features. To minimize artificial modifications of the apatite grains during SEM analysis, the samples were simply located on standard Scotch tape without a coat- ing procedure and then analyzed at a variable pressure mode. Shan et al. (2013) showed that extended chemical mapping up to $\sim 2 \mathrm{~h}$, even at high SEM beam currents $(1000 \mathrm{pA})$, does not cause any detectable modification of (U-Th)/He ages for the Durango apatite standard. After SEM analysis, all the grains were examined under a stereomicroscope to determine their physical dimensions. Most of the selected apatite grains were in the range of $80-250$ $\mu \mathrm{m}$.

Two to five apatite grains were wrapped together in $\mathrm{Nb}$ tubes, and each of the sample packets was placed in a well within a stainless-steel planchette. 
Table 1. (U-Th)/He Data for Apatite in Metamorphic Rocks of Phyllite-Quartzite Unit (PQU) from Kythera and the Southeastern Peloponnese

\begin{tabular}{|c|c|c|c|c|c|c|c|c|c|c|c|c|c|c|c|c|c|}
\hline $\begin{array}{l}\text { Sample } \\
\text { name }\end{array}$ & Location & $\begin{array}{c}\mathrm{U} \\
\text { (fmol) }\end{array}$ & $1 \sigma$ & $\begin{array}{c}\text { Th } \\
\text { (fmol) }\end{array}$ & $1 \sigma$ & $\begin{array}{c}\mathrm{Sm} \\
(\mathrm{fmol})\end{array}$ & $1 \sigma$ & $\begin{array}{c}{ }^{4} \mathrm{He} \\
\text { (fmol) }\end{array}$ & $1 \sigma$ & $F_{\mathrm{T}}$ & $\begin{array}{l}\text { No. } \\
\text { grains }\end{array}$ & $\begin{array}{c}(\mathrm{U}-\mathrm{Th}) / \mathrm{He} \\
\text { age (Ma) }\end{array}$ & $1 \sigma^{\mathrm{a}}$ & $\%$ & $\begin{array}{c}\mathrm{U} \\
(\mathrm{ppm})^{\mathrm{b}}\end{array}$ & $\begin{array}{c}\mathrm{Th} \\
(\mathrm{ppm})^{\mathrm{b}}\end{array}$ & $\begin{array}{c}\mathrm{Sm} \\
(\mathrm{ppm})^{\mathrm{b}}\end{array}$ \\
\hline T04_1 & Kythera & 4.82 & .53 & 28.4 & 1.6 & 1852 & 46 & .22 & .02 & .87 & 1 & 15.5 & 2.3 & 15 & .04 & .2 & 9.9 \\
\hline $04 \_2$ & Kythera & 29.3 & 2.0 & 216 & 14 & 2217 & 58 & 1.47 & .06 & .88 & 1 & 16.2 & 1.5 & 9 & .25 & 1.8 & 12 \\
\hline T04-1 & Kythera & 101 & 2.1 & 251 & 8.0 & 8703 & 162 & .82 & .02 & .88 & 2 & 4.4 & .3 & 6 & .96 & 2.3 & 52 \\
\hline T04-6 & Kythera & 15.3 & 1.2 & 386 & 14 & 2814 & 41 & 1.20 & .04 & .89 & 1 & 9.9 & .7 & 7 & .13 & 3.3 & 16 \\
\hline T05-1 & Kythera & 311 & 5.1 & 2003 & 35 & 10,265 & 224 & 7.65 & .23 & .86 & 4 & 8.9 & .6 & 6 & 6.8 & 43 & 141 \\
\hline T05-2 & Kythera & 35.1 & 1.9 & 198 & 8.8 & 4260 & 123 & 1.53 & .05 & .83 & 3 & 17.1 & 1.3 & 7 & 1.3 & 7.2 & 100 \\
\hline T05-3 & Kythera & 257 & 6.0 & 2084 & 60 & 21,281 & 412 & 7.80 & .23 & .85 & 6 & 9.4 & .6 & 7 & 4.0 & 31 & 208 \\
\hline T05-4 & Kythera & 74.7 & 1.5 & 579 & 19 & 4733 & 125 & 2.93 & .09 & .84 & 2 & 12.9 & .9 & 7 & 1.8 & 14 & 73 \\
\hline T05_2 & Kythera & 13.7 & .86 & 92.3 & 8.1 & 963 & 29 & .34 & .05 & .77 & 2 & 9.7 & 1.7 & 17 & .45 & 3.0 & 20 \\
\hline T06_1 & Kythera & 261 & 5.6 & 34.0 & 1.2 & 1515 & 37 & 1.87 & .06 & .67 & 1 & 8.0 & .5 & 7 & 47 & 6.0 & 172 \\
\hline T06_2 & Kythera & 382 & 9.9 & 31.9 & 1.5 & 1997 & 38 & 3.08 & .09 & .69 & 1 & 8.9 & .6 & 7 & 64 & 5.2 & 211 \\
\hline D43_3 & Kythera & 50.1 & 2.3 & 149 & 5.1 & 1129 & 34 & .74 & .02 & .74 & 3 & 9.1 & .7 & 7 & 1.7 & 4.9 & 24 \\
\hline D01-1 & SE Peloponnese & 427 & 11 & 1060 & 31 & 13,129 & 256 & 7.17 & .22 & .74 & 4 & 11.0 & .7 & 7 & 44 & 107 & 859 \\
\hline D01-2 & SE Peloponnese & 1329 & 31 & 2044 & 58 & 16,508 & 449 & 15.6 & .47 & .76 & 4 & 8.9 & .6 & 7 & 117 & 175 & 915 \\
\hline D10_g2 & SE Peloponnese & 10.5 & 1.7 & 47.6 & 5.2 & 740 & 26 & .17 & .01 & .82 & 1 & 7.2 & .9 & 12 & .24 & 1.1 & 11 \\
\hline
\end{tabular}

a $F_{\mathrm{T}}$ correction error of $3 \%$ is included.

b Estimates based on measured grain dimensions converted to mass. 


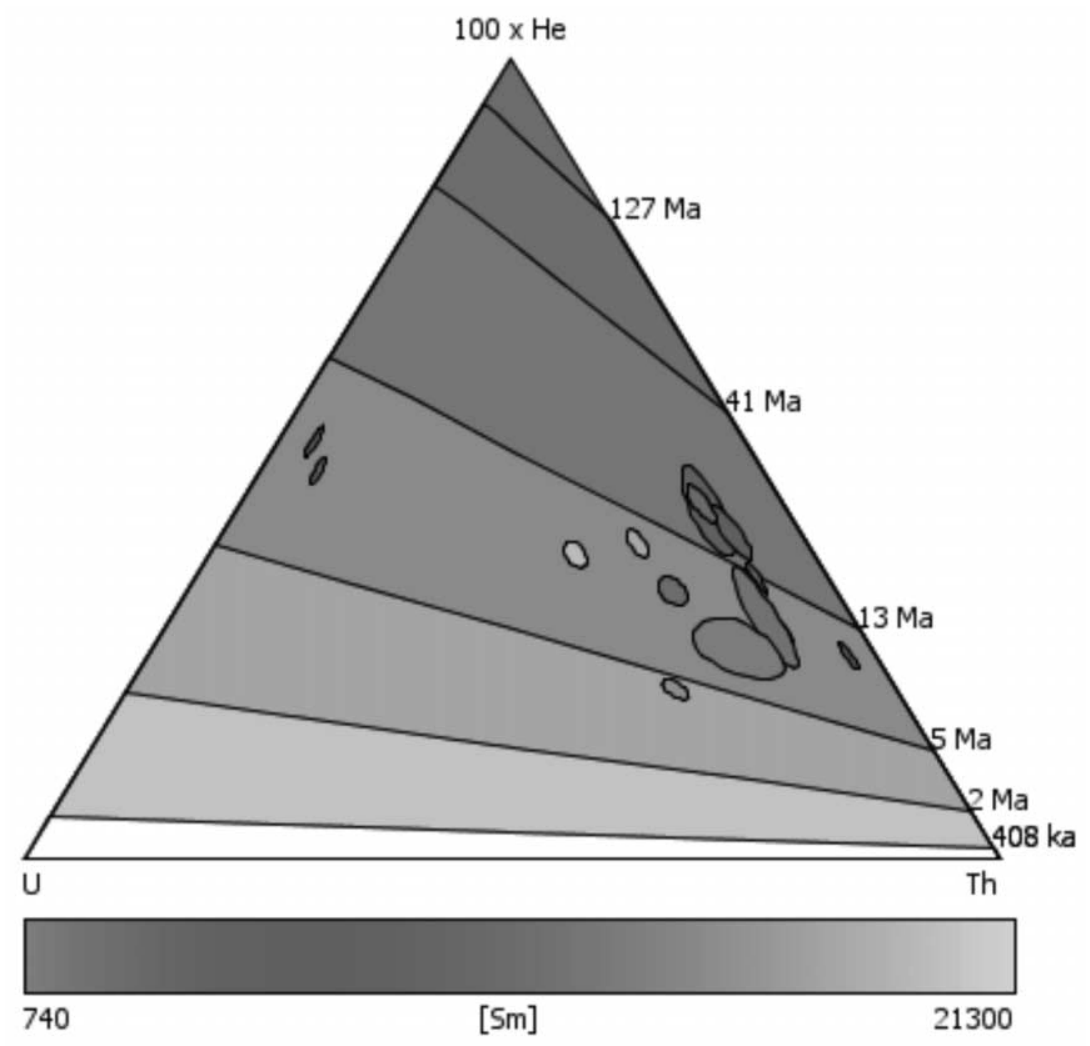

Figure 5. HelioPlot showing the distribution of U-Th-(Sm)-He data among different apatites on a ternary diagram and log-ratio plot (Vermeesch 2010).

The loaded planchette was sealed in a high vacuum, and individual packets were heated using a diode laser at $7 \mathrm{amp}$ for $3 \mathrm{~min}$. The extracted gas was mixed with a known amount of $>99.99 \%$ pure ${ }^{3} \mathrm{He}$ spike, purified with an NP-10 getter, and then analyzed with a Pfeiffer-Balzer Prisma quadrupole mass spectrometer. All the grains were reextracted twice to confirm complete He degassing of samples. Most of the samples yielded negligible amounts of gas even after the first reextractions. For all samples, the second reextraction contributed less than $0.5 \%$ of the total measured ${ }^{4} \mathrm{He}$. Procedural blanks were measured after every three samples. Durango apatite standards were measured every 10 samples. The entire He analysis sequence was performed in an automatic mode using LabView (National Instruments) and autoclick (MurGee) codes. The degassed sample packets were retrieved from the sample chamber, mixed with $\sim 0.05 \mathrm{~mL}$ of U-Th-Sm spike, and then dissolved in $5 \%$ nitric acid for inductively coupled plasma mass spectrometer (ICPMS) analysis. Analytical errors for the (U-Th)/He ages were propagated using Monte Carlo simulation. An additional 3\% of $\alpha$-recoil correction errors at $1 \sigma$ level were included in the error calculation.
The analytical errors on the ages generally range from $\sim 3 \%$ to $14 \%(1 \sigma$; table 1$)$, mainly because of the very low U-Th contents in some of the apatite grains. Figure 5 displays a HelioPlot ternary diagram (Vermeesch 2010) efficiently demonstrating the U-Th-(Sm)-He abundances and resulting ages.

\section{Results}

Many apatite grains from metamorphic rocks in Kythera and the Peloponnese yielded very low U$\mathrm{Th}(<\sim 0.01 \mathrm{ppm})$ or He $(<\sim 0.1 \mathrm{fmol})$ contents, which was prohibitive in determining reliable $(\mathrm{U}-\mathrm{Th}) / \mathrm{He}$ ages. Meaningful and precise AHe ages were obtained, however, for four samples from Kythera (T04, T05, T06, D43) and two samples from the Peloponnese (D01, D10). These samples yielded AHe ages ranging from $4.4 \pm 0.3(1 \sigma)$ to $17.1 \pm 1.3$ Ma. The sample locations and calculated ages are shown in figures 3 and 4 and are listed in table 1 . From Kythera sample T05, we obtained five multigrain (U-Th)/He ages in the range of 8.9-16.2 Ma. Although the ages are widely scattered, three young ages $(8.9,9.4$, and $9.7 \mathrm{Ma})$ are tightly clustered, with 
a mean age of $9.2 \pm 0.8 \mathrm{Ma}$. The remaining two ages (12.9 and $17.1 \mathrm{Ma}$ ) are old and scattered and are probably caused by small inclusions or coating of U-Th-rich phases. The most likely AHe age for TO5 is $9.2 \pm 0.8 \mathrm{Ma}$.

For sample T04, the $(\mathrm{U}-\mathrm{Th}) / \mathrm{He}$ ages are scattered from $4.4 \pm 0.3$ to $16.2 \pm 1.5 \mathrm{Ma}$. Although the two oldest ages (15.5 and 16.2 Ma) seem to be identical in terms of their uncertainties, the available ZFT age from the same sample is $10.9 \pm 0.9(1 \sigma) \mathrm{Ma}$, suggesting that these two $(\mathrm{U}-\mathrm{Th}) / \mathrm{He}$ ages are significantly older than the expected AHe age. The two young ages $(4.4 \pm 0.3$ and $9.9 \pm 0.7 \mathrm{Ma})$ are not identical, and it is difficult to determine the true AHe age. However, $9.9 \pm 0.7 \mathrm{Ma}$ is consistent with clustered ages from nearby sample T05 and very similar to the other AHe ages in the same unit. Sample T06 yielded AHe ages of $8.9 \pm 0.6$ and $8.0 \pm 0.5 \mathrm{Ma}$, which are slightly older than the apatite fission-track (AFT) age $(6.5 \pm 1.0 \mathrm{Ma}[1 \sigma]$; Marsellos et al. 2010a) for the same sample. Such an inverted relationship is also observed in sample D43, which yields an AHe age of $9.1 \pm 0.7 \mathrm{Ma}$ and an AFT age of $7.0 \pm 1.7 \mathrm{Ma}(1 \sigma)$. Two southeastern Peloponnese samples show no significant inverted relationship, and they are located below the detachment-generated $(\mathrm{U}-\mathrm{Th}) / \mathrm{He}$ ages of $7.1 \pm 0.5$ Ma (D10; glaucophane-mica-schist) and $8.8 \pm 0.5$ $\mathrm{Ma}$ (D01; quartzose gneiss). The possible causes of the old AHe apparent ages are discussed in the following section.

Apatites from the gneiss sample (T06) show low $\mathrm{Th} / \mathrm{U}$ values $(\sim 0.1)$ with high absolute concentrations of $U$ ( 47-55 ppm). In contrast, most other Kythera apatites yielded relatively high $\mathrm{Th} / \mathrm{U}$ with significantly lower U concentrations.

\section{Discussion}

Metamorphic Gradient along the Forearc Ridge. The spatial distribution of metamorphic grade is likely linked to the different subduction and exhumation trajectories of corresponding rock units in an evolving accretion geometry. Even in a small area, such as the Kythera Strait, rock units show a wide range of maximum burial depths (6-30 km or even deeper) indicating that they experienced variable subduction-exhumation trajectories (Marsellos et al. $2010 b$ ). Rock units from variable maximum depths are structurally juxtaposed, but it is unclear whether the juxtaposition occurred during subduction or exhumation. For example, flysch sandstones from Pindos unit rocks that were deposited on the overriding Eurasian plate (Hall et al. 1984) experienced temperatures above the apatite closure temperature $\left(80^{\circ}-120^{\circ} \mathrm{C}\right)$ but not higher than the ZFT closure temperature $\left(190^{\circ} \mathrm{C}\right)$, implying that they did not experience high- $P$ metamorphism and probably escaped the subduction $P$ - $T$ trajectory during the period of 23-15 Ma (Marsellos et al. 2010b).

Age Interpretation. Intrasample scatter of (U-Th)/ He apparent ages, some of which are older than coexisting AFT apparent ages (i.e., the inverted AHe-AFT age relationship) is not uncommon in AHe thermochronology and has been attributed to several different processes, including (1) differential He diffusion properties mainly controlled by radiation damage in individual apatite crystals (Green et al. 2006; Shuster et al. 2006; Flowers et al. 2009; Flowers and Kelley 2012); (2) uneven distribution of U-Th within single-apatite grains, leading to incorrect alpha-recoil corrections and resulting in complex ${ }^{4} \mathrm{He}$ profiles and radiation damage distributions (Hourigan et al. 2005; Farley et al. 2011; Ault and Flowers 2012); (3) fragmentation of originally larger grains, resulting in AHe age that represents only a portion of He distribution in the original grain (Beucher et al. 2012; Brown et al. 2013); (4) injection of alpha particles from U-Th-rich inclusions such as zircon, monazite, or allanite (House et al. 1997; Ehlers and Farley 2003; Vermeesch et al. 2007); and (5) implantation of ${ }^{4} \mathrm{He}$ from adjacent U-Th-rich phases (Farley 2003; Spiegel et al. 2009; Murray et al. 2011).

Differential He diffusion parameters among different grains in the same sample may be amplified when apatite grains have a relatively large intergrain variation of $\mathrm{eU}(=[\mathrm{U}]+0.235[\mathrm{Th}])$ and have experienced prolonged residence at the shallow crustal level (Flowers and Kelley 2012). However, the ZFT ages from the Kythera and Peloponnese samples are in the range of 9.1-21.3 Ma, suggesting that the rocks experienced a subduction-related metamorphic reheating event at conditions above $\sim 240^{\circ} \pm 50^{\circ} \mathrm{C}$ (ZFT closure temperature; Brandon et al. 1998). Therefore, a significant portion of the radiation damage accumulated before the reheating event must have been removed during the thermal event, efficiently homogenizing previous radiation damage contrast. Moreover, the samples used in our study do not show the positive eU-age relationship (fig. 6) expected from the radiation damage model, suggesting that a variation of intergrain $\mathrm{He}$ diffusion properties is not the main cause of the apparently old AHe ages.

Heterogeneous distributions of $U$ and Th within apatite crystals may cause scattered apparent ages in at least two different ways (Farley et al. 2011). First, uneven U-Th distribution can lead to erroneous estimation of alpha-recoil correction factors, 

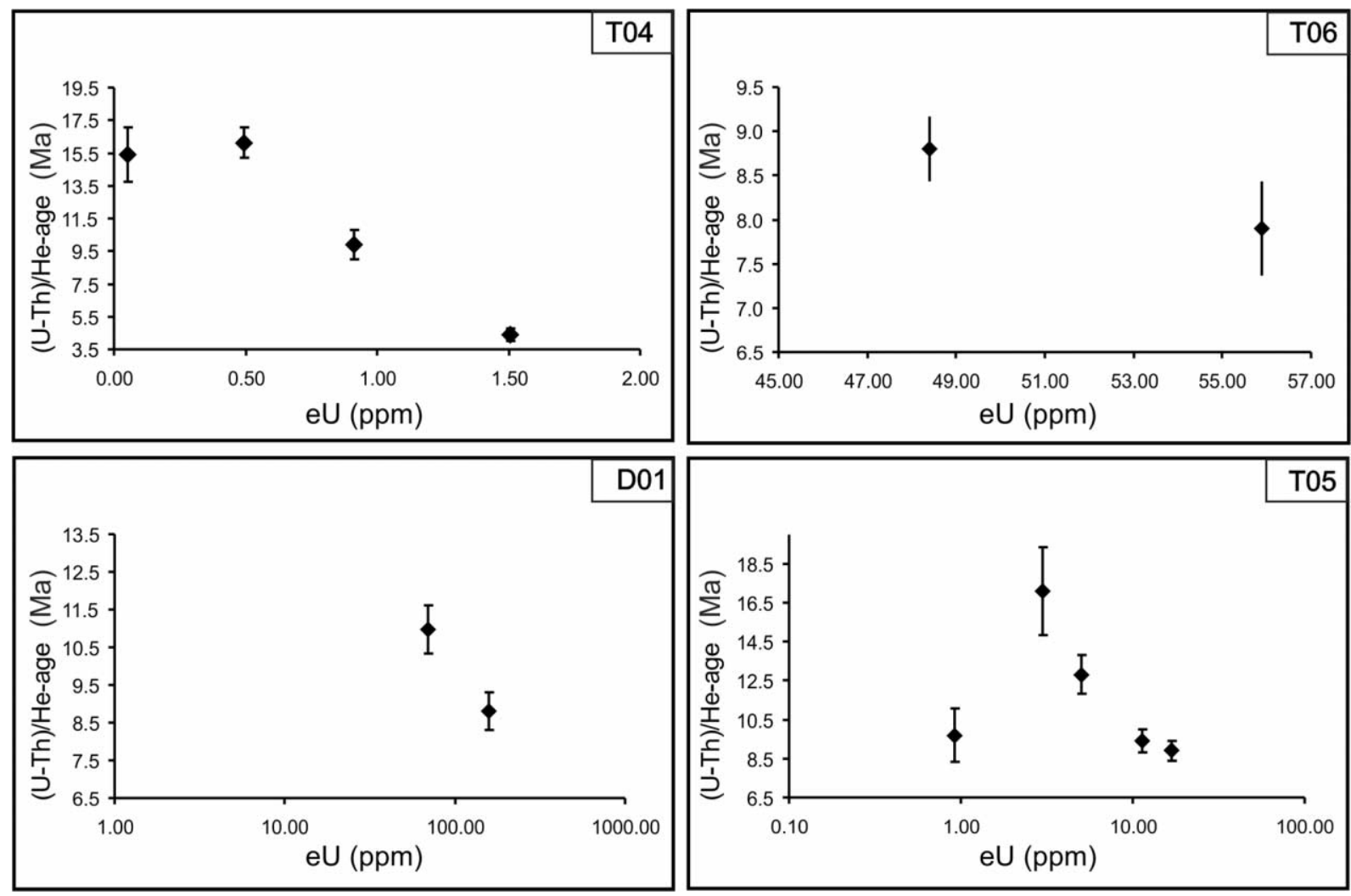

Figure 6. (U-Th)/He age versus eU $(=[\mathrm{U}]+0.235[\mathrm{Th}])$ plot. The negative correlation identified from the four samples indicates that the old and scattered ages are potentially caused by U-Th-rich inclusions or that such phases existed near the apatite grains inducing alpha implantation into the apatite grains used for our analysis.

causing apparently young or old $(\mathrm{U}-\mathrm{Th}) / \mathrm{He}$ ages. Second, U-Th zonation would produce uneven ${ }^{4} \mathrm{He}$ distributions, resulting in differential fractional $\mathrm{He}$ losses for individual apatite grains. However, this effect can cause an age bias of only a few percent even for significantly zoned (up to $40 \%$ eU corerim contrast) apatite grains (Ault and Flowers 2012). Previous fission-track analysis indicates that the U zonation is insignificant for the Kythera and Peloponnese apatites, so that uneven U-Th distribution may have contributed only a small portion of the age scatter.

Fragmentation of originally large grains can also yield scattered AHe ages because each fragment represents a different portion of He diffusion profile in its parent grain (Brown et al. 2013). A fragment from the core of the apatite grain is expected to have a higher He concentration than a fragment from the margin, therefore yielding apparently older AHe age. The resulting spread of AHe ages would be particularly significant for samples that experienced slow cooling, an extended stay in a partial retention zone, or minor reheating (Beucher et al. 2012), mainly because such thermal histories cause a prominent He gradient. In contrast, a grain that experienced rapid cooling is expected to have a relatively flat ${ }^{4} \mathrm{He}$ concentration for a significant portion of the grain and therefore to be less sensitive to the fragmentation effect. For example, a recent numerical modeling suggests that a sample cooled at a rate of $10^{\circ} \mathrm{C} / \mathrm{m}$.yr. would yield AHe ages within a range of $\sim 7 \%$ (Brown et al. 2013). Therefore, the Kythera and Peloponnese samples, which experienced rapid cooling at a comparable or even higher rate $\left(>10^{\circ} \mathrm{C} / \mathrm{m} . y r.\right)$, are expected to be even less vulnerable to this effect.

The most important cause of the scattered AHe ages is probably either point (4) or point (5) above, or a combination of the two. Although the metamorphic apatite grains were carefully observed under the stereomicroscope, many of the grains were not transparent, hampering detailed examination of their internal volume, and it was difficult to identify small inclusions. Also, potential implantation of alpha particles from adjacent U-Th-rich grains is a viable explanation of the observed old apparent $\mathrm{AHe}$ ages. The inverse relationship between $\mathrm{AHe}$ age and eU (fig. 6) further supports these possibil- 
ities because the low-eU apatite would be more vulnerable to such inclusions or neighboring phases (Spiegel et al. 2009). Because the U-Th contents are relatively low in the apatite grains used for our study, even a small inclusion of zircon or monazite or a thin film of oxide on surfaces of apatite grains can cause a significant increase in the $(\mathrm{U}-\mathrm{Th}) / \mathrm{He}$ ages. For a hypothetical apatite grain with $[\mathrm{U}]=$ $[\mathrm{Th}]=0.1 \mathrm{ppm}$ and radius $=50 \mu \mathrm{m}$, one small zircon inclusion with $[\mathrm{U}]=[\mathrm{Th}]=200 \mathrm{ppm}$ and radius $=3 \mu \mathrm{m}$ can result in an AHe age increase of $\sim 43 \%$.

Because of the reasons discussed above, the young and clustered AHe ages are likely to be more reliable than older apparent ages. The young and clustered $(\mathrm{U}-\mathrm{Th}) / \mathrm{He}$ ages from the four Kythera samples located below the detachment can be represented as $9.2 \pm 0.8 \mathrm{Ma}$ (T05) and $9.9 \pm 0.7 \mathrm{Ma}$ (T04) for metagranite; $9.1 \pm 0.7 \mathrm{Ma}$ (D43) for glaucophane-mica-schist; and $8.5 \pm 0.6 \mathrm{Ma}$ (T06) for gneiss. Two southeastern Peloponnese samples also located below the detachment generated more reliable $(\mathrm{U}-\mathrm{Th}) / \mathrm{He}$ ages of $7.2 \pm 0.9 \mathrm{Ma}(\mathrm{D} 10$; glaucophane-mica-schist) and $8.9 \pm 0.6 \mathrm{Ma}$ (D01; quartzose gneiss).

Integration of (U-Th)/He and Fission-Track Data. As summarized in the previous section, the apparently old (> 10 Ma) and scattered AHe ages for the Kythera and Peloponnese samples are probably due to U-Th-rich inclusions or adjacent phases. The remaining AHe ages are concentrated in the range of 7-10 Ma, which likely represents the timing of when the Kythera and Peloponnese samples passed through the He closure temperature of apatite. The young and reliable AHe ages from the two Peloponnese D10 and D01 samples $(7.1 \pm 0.5,8.8 \pm$ $0.5 \mathrm{Ma}$ ) are identical to corresponding AFT ages $(6.8 \pm 3.8,9.8 \pm 1.3 \mathrm{Ma})$ within their uncertainties. For Kythera samples T06 (gneiss) and D43 (glaucophane mica-schist), the AHe ages are slightly older than the previously reported AFT ages of T06 $(6.5 \pm 1.0 \mathrm{Ma}, 1 \sigma)$ and D43 $(7.0 \pm 1.7 \mathrm{Ma}, 1 \sigma$; Marsellos et al. 2010a). This is probably related to (1) rapid cooling in these samples, which caused the closure temperatures of AHe and AFT to be almost identical, and (2) previously reported AFT age errors, which reflect the lower precision of fission-track analyses but could be slightly underestimated due to very low U-Th content.

Apatite with very low uranium concentration may provide only a very small number of spontaneous fission-tracks (1-5) per 20-30 grains. The errors on the AFT ages reflect the small number of spontaneous tracks compared with 1000-2000 induced tracks. Miocene or younger apatites of less than $5 \mathrm{ppm}$ or zircons with less than $50 \mathrm{ppm}$, therefore, give ages with very low precision (Garver et al. 2002; Bernet and Garver 2005), but these results tend to be accurate because etched tracks are easily identified compared to inclusions (Montario et al. 2008). The whole-grain (U-Th)/He ages may have higher analytical precision but could be affected by U-Th-rich inclusions. Precision and accuracy are both not in favor in those two thermochronological techniques. Precision is very high in $(\mathrm{U}-\mathrm{Th}) / \mathrm{He}$, as this technique determines $\mathrm{He}^{3}$ and $\mathrm{He}^{4}$ by ICP-MS but provides relatively low accuracy due to the factors summarized above. In contrast, the fissiontrack system allows measurement on the surface free of inclusions, permitting high accuracy but very low precision in low-uranium minerals (low count of induced tracks) or very young minerals (low count on spontaneous tracks).

Both dating systems are further limited when the grains are rich in inclusions such as the Aegean apatites. The fission-track system is based on optical microscopic measurements and is not mainly influenced by inclusions of less than $1 \mu \mathrm{m}$, as those inclusions are not prominent or are "invisible" under this magnification of the optical microscope and, consequently, not countable. Inclusions of less than $1 \mu \mathrm{m}$ cannot be considered as spontaneous tracks (considering a nonunderetched sample), and they are instantly disregarded. Inclusions of higher than $1 \mu \mathrm{m}$ diameter can be simply disregarded. (U$\mathrm{Th} / \mathrm{He}$ requires SEM-energy dispersive X-ray (EDX) analysis or an equivalent electron microprobe analysis to identify the presence of inclusions in mineral shallow subsurface but not inside. Sequential etching times of minerals for fission-track dating permit a wide range of ages to be determined by numerous mineral conditions, including nontransparent minerals and rich-inclusion minerals. In terms of investigating the cooling histories of relatively young metamorphic rocks of rich-inclusion minerals, it is, therefore, helpful to integrate data from both fission-track and (U-Th)/He systems.

Tectonic Implications. The low- $T$ thermal history of the southeastern Peloponnese and Kythera was previously constrained using fission-track dating of metamorphic apatite grains (Marsellos et al. 2010a). The new apatite $(\mathrm{U}-\mathrm{Th}) / \mathrm{He}$ ages provide thermal histories for an even lower temperature range. The pooled apatite $(\mathrm{U}-\mathrm{Th}) / \mathrm{He}$ ages from Kythera and the southeastern Peloponnese are slightly older than AFT ages from the same area (figs. 3, 4). Although there is clear evidence of unsupported ${ }^{4} \mathrm{He}$ in some apatite grains used for $(\mathrm{U}-\mathrm{Th}) / \mathrm{He}$ dating, the most likely AHe ages are grouped in the range of $\sim 8.0$ 
9.9 Ma for the Kythera samples (T04, T05, T06, D43). These data indicate rapid cooling (i.e., between zircon and apatite annealing zones) and exhumation of the HP rocks in the Kythera Strait and the surrounding areas of the Hellenic forearc ridge through the closure interval of the fission-track and He systems $\left(<200^{\circ}\right.$ to $\left.>40^{\circ} \mathrm{C}\right)$.

The new (U-Th)/He results combined with the reported fission-track data (fig. 2) may imply that the Miocene cooling and exhumation rates progressively increase from Crete toward Kythera and the southeastern Peloponnese. Zircon and the limited apatite thermochronologic data from the "lower plate" along the forearc ridge may imply that the Kythera Strait corresponds to the most recently exhumed area of HP/LT metamorphic rocks in the Hellenic forearc ridge. Furthermore, the timing of exhumation is inversely correlated with the metamorphic grade, which is higher in the Kythera Strait (younger cooling age) and lower in the Peloponnese and Crete areas (older cooling age). This pattern suggests that the SW segment of the Hellenic arc, which corresponds to the Kythera Strait, experienced relatively rapid decompression since its peak metamorphism compared to the adjacent areas of the arc (central-north Peloponnese and central-eastern Crete). These are two prominent patterns that suggest a correlation between metamorphic conditions' increasing distance from the edges of the Hellenic arc toward the center (Kythera and southern Peloponnese; fig. 2). This pattern corresponds with an increasing rate of exhumation.

The Tripolis unit experienced thrust imbrication associated with mild metamorphism at temperature conditions of $\sim 260^{\circ} \mathrm{C}$ (Rahl et al. 2005). Tripolis flysch was underthrust beneath the Pindos imbricated folded carbonates. Thermochronologic data indicate that the Tripolis and Pindos units of Kythera were thrust to only crustal levels, shallower than the partial annealing zone of zircon (corresponding to $240^{\circ} \pm 50^{\circ} \mathrm{C}$ ). Therefore, these units experienced only limited subduction as a part of the lower plate between 23 and $15 \mathrm{Ma}$ (Marsellos et al. 2010b). A limited subduction can also be inferred by the unmetamorphosed Pindos flysch sediments on Crete, which were at the surface when they were unconformably overlain by Neogene sediments between 15 and $12 \mathrm{Ma}$ (Postma et al. 1993) and by the overlying uppermost (UM) tectonic unit of the Cretan nappe pile (Seidel et al. 1976). The nappes showed a rapid cooling at $16 \mathrm{Ma}$, when UM rocks were cooled below the apatite annealing zone (Thomson et al. 1999). This time interval corresponds to the activity of a series of detachment faults, which facilitated exhumation of HP rocks elsewhere in the Aegean (Fassoulas et al. 1994; Kilias et al. 1994; Jolivet et al. 1996, 1998; Thomson et al. 1999; Marsellos et al. 2010a). Those two events, extension and the occurrence of detachment faults, coincide with a shallow subduction of the unmetamorphosed Tripolis unit and Pindos flysch rocks in Crete and Kythera during 23-15 Ma. Cretan and Kythera "upper plate" rocks show a coeval exhumation, while Kythera lower plate rocks such as the PQU rocks show a younger rapid exhumation that took place after the central Peloponnese and Cretan PQU rocks' exhumation.

Structural and thermochronologic observations of arc-parallel extension in the Hellenic arc (Marsellos and Kidd 2008; Marsellos et al. 2010a) prompted evaluation and integration of the event into the dynamics of arc expansion and extension (van Hinsbergen and Schmid 2012). During the Late Miocene (15 Ma), arc expansion reached a peak in velocity, probably due to faster rollback. This is because rapid arc expansion cannot take place with only arc-normal extension. Arc-parallel (along-thearc) extension facilitated the augmentation of the arc curvature and subsequent exhumation of $\mathrm{HP}$ rocks via arc-parallel detachments (Marsellos et al. 2010a). The Kythera Strait experienced the highest rate of rollback and, therefore, the greatest stretching along the axis of the arc increase in the length of the arc in the Mediterranean area, which eventually caused Late Miocene exhumation of HP rocks in the Kythera Strait.

HP rocks with an arc-parallel stretching lineation in the Kythera to the southeast of the Peloponnese area were at temperatures within the upper zircon partial annealing zone $\left(\mathrm{ZPAZ} ; 250^{\circ} \pm 50^{\circ} \mathrm{C}\right)$ during the interval of $\sim 13$ to $9 \mathrm{Ma}$. It is likely that arcparallel extension started after an Early to Middle Miocene differential rollback and ended at $\sim 9 \mathrm{Ma}$, when the gneissic rocks cooled below the ZPAZ. The apatite $(\mathrm{U}-\mathrm{Th}) / \mathrm{He}$ ages indicate that postdetachment brittle faults facilitated the final exhumation and faulting into the PQU rocks' postdating $\sim 9 \mathrm{Ma}$.

\section{Conclusions}

The apatite (U-Th)/He ages from metasedimentary rocks of the South Aegean region in the Kythera Strait are concordant with the previously reported ZFT and AFT cooling ages. These results indicate that Kythera and southern Peloponnese HP rocks, which correspond to more than one geological unit, experienced similar shallow exhumation paths during the Middle to Late Miocene. Gneissic lenses show slightly younger exhumation ages than the 
PQU rocks, implying that detachment and exhumation of those exotic unit rocks followed the PQU rocks' exhumation. The arc-parallel extension dominated the arc-normal regional extension be- tween 12-13 and 8-9 Ma due to rapid, differential rollback of the slab. Arc-parallel extension was active for an $\sim 5 \mathrm{~m}$.yr. interval during the regional arc expansion.

\section{REFER E N C ES CITED}

Angelier, J., and Le Pichon, X. 1980. Néotectonique horizontale et verticale de l'Egée: subduction et expansion. In Géologie des Chaînes Alpines Issues de la Téthys. International Geological Congress, 26th (Paris, 1980), Colloq. C5. Mem. Bur. Rech. Geol. Min. 115:249-260.

Ault, A. K., and Flowers, R. M. 2012. Is apatite U-Th zonation information necessary for accurate interpretation of apatite (U-Th)/He thermochronometry data? Geochim. Cosmochim. Acta 79:60-78.

Bernet, M., and Garver, J. I. 2005. Fission-track analysis of detrital zircon. Rev. Mineral. Geochem. 58:205238.

Beucher, R.; Brown, R.; Roper, S.; Stuart, F.; and Persano, C. 2012. What to pick or not to pick? revisiting the question of grain selection for applying the apatite (U$\mathrm{Th}) / \mathrm{He}$ thermochronometry technique. In Abstracts, 13th Thermochronology Conference, Guilin, China, p. 3.

Biryol, C. B.; Beck, S. L.; Zandt, G.; and Ozacar, A. A. 2011. Segmented African lithosphere beneath the Anatolian region inferred from teleseismic P-wave tomography. Geophys. J. Int. 184:1037-1057. doi:10 $.1111 / j .1365-246 X .2010 .04910 . x$.

Bonneau, M. 1984. Correlation of the Hellenic nappes in the south-east Aegean and their tectonic reconstruction. Geol. Soc. Lond. Spec. Publ. 17:517-527.

Bornovas, I., and Rontogianni-Tsiabaou, T. 1983. Geological map of Greece. Athens, Institute of Geology and Mineral Exploration.

Bradley, K. E.; Vassilakis, E.; Hosa, A.; and Weiss, B. P. 2013. Segmentation of the Hellenides recorded by Pliocene initiation of clockwise block rotation in central Greece. Earth Planet. Sci. Lett. 362:6-19.

Brandon, M. T.; Roden-Tice, M. R.; and Garver, J. I. 1998. Late Cenozoic exhumation of the Cascadia accretionary wedge in the Olympic Mountains, northwest Washington state. Geol. Soc. Am. Bull. 110:985-1009.

Brix, M. R.; Stockhert, B.; Seidel, E.; Theye, T.; Thomson, S. N.; and Kuster, M. 2002. Thermobarometric data from a fossil zircon partial annealing zone in high pressure-low temperature rocks of eastern and central Crete, Greece. Tectonophysics 349:309-326.

Brown, R.; Beucher, R.; Roper, S.; Persano, C.; Stuart, F.; and Fitzgerald, P. 2013. Natural age dispersion arising from the analysis of broken crystals. I. Theoretical basis and implications for the apatite (U-Th)/He thermochronometer. Geochim. Cosmochim. Acta 122: 478-497.

Brun, J.-P., and Faccenna, C. 2008. Exhumation of highpressure rocks driven by slab rollback. Earth Planet. Sci. Lett. 272:1-7.

Christodoulou, G. 1965. Quelques observations sur la géologie de Cythère et examen micropaléontologique des formations néogènes de l'île. Bull. Soc. Geol. Greece 6:385-399.

Dewey, J. F. 1981. Episodicity, sequence and style at convergent plate boundaries. In The continental crust and its mineral deposits. Geol. Assoc. Can. Spec. Pap. 20: 553-572.

Dewey, J. F.; Helman, M. L.; Turco, E.; Hutton, D. W. H.; and Knott, S. D. 1989. Kinematics of the western Mediterranean. In Coward, M. P., and Dietrich, D., eds. Alpine tectonics. Geol. Soc. Lond. Spec. Publ. 45:265283.

Duermeijer, C. E.; Krijgsman, W.; Langereis, C. G.; and ten Veen, J. H. 1998. Post-early Messinian counterclockwise rotations on Crete: implications for Late Miocene to recent kinematics of the southern Hellenic arc. Tectonophysics 298:177-189.

Ehlers, T. A., and Farley, K. A. 2003. Apatite (U-Th)/He thermochronometry: methods and applications to problems in tectonic and surface processes. Earth Planet. Sci. Lett. 206:1-14.

Faccenna, C.; Jolivet, L.; Piromallo, C.; and Morelli, A. 2003. Subduction and the depth of convection in the Mediterranean mantle. J. Geophys. Res. 108:2099. doi: 10.1029/2001JB001690.

Farley, K. A. 2003. Problematic samples for apatite (UTh)/He dating: some possible causes and solutions. American Geophysical Union Fall Meeting 2003, abstract V22G-06.

Farley, K. A.; Shuster, D. L.; and Ketcham, R. A. 2011. $\mathrm{U}$ and $\mathrm{Th}$ zonation in apatite observed by laser ablation ICPMS, and implications for the (U-Th)/He system. Geochim. Cosmochim. Acta 75:4515-4530.

Fassoulas, C.; Kilias, A.; and Mountrakis, D. 1994. Postnappe stacking extension and exhumation of highpressure/low-temperature rocks in the island of Crete, Greece. Tectonics 13:127-138.

Flowers, R. M., and Kelley, S. A. 2012. Interpreting data dispersion and "inverted" dates in apatite (U-Th)/He and fission-track datasets: an example from US midcontinent. Geochim. Cosmochim. Acta 75:5169-5186.

Flowers, R. M.; Ketcham, R. A.; Shustr, D. L.; and Farley, K. A. 2009. Apatite (U-Th)/He thermochronometry using a radiation damage accumulation and annealing model. Geochim. Cosmochim. Acta 73:2347-2365.

Freyberg, B. 1967. Die Neogen Diskordanz in central Kythira. Prakt. Akad. Athinon. 42:361-381.

Garver, J. I.; Riley, B. C. D.; and Wang, G. 2002. Partial resetting of fission tracks in detrital zircon. European Fission-Track Conference, Cadiz, Spain. Geotemas 4: 73-75.

Gerolymatos, I. K. 1994. Metamorphose und Tectonik 
der Phyllit-Quartzit-Serie und der Tyros-Schichten auf dem Peloponnes und Kythira. Berl. Geowiss. Abh. 164: $1-101$.

Gesret, A.; Laigle, M.; Diaz, J.; Sachpazi, M.; Charalampakis, M.; and Hirn, A. 2011. Slab top dips resolved by teleseismic converted waves in the Hellenic subduction zone. Geophys. Res. Lett. 38:L20304. doi: 10.1029/2011GL048996.

Govers, R., and Wortel, M. J. R. 2005. Lithosphere tearing at STEP faults: response to edges of subduction zones. Earth Planet. Sci. Lett. 236:505-523.

Green, P. F.; Crowhurst, P. V.; Duddy, I. R.; Japsen, P.; and Holford, S. P. 2006. Conflicting (U-Th)/He and fission track ages in apatite: enhanced He retention, not anomalous annealing behaviour. Earth Planet. Sci. Lett. 250:407-427.

Hall, R.; Audley-Charles, M. G.; and Carter, D. J. 1984. The significance of Crete for the evolution of the Eastern Mediterranean. In Dixon, J. E., and Robertson, A. H. F., eds. The geological evolution of the Eastern Mediterranean. Geol. Soc. Lond. Spec. Publ. 17:499-516.

Hourigan, J. K.; Reiners, P. W.; and Brandon M. T. 2005. $\mathrm{U}-\mathrm{Th}$ zonation-dependent alpha-ejection in $(\mathrm{U}-\mathrm{Th}) / \mathrm{He}$ chronometry. Geochim. Cosmochim. Acta 69:3349_ 3365.

House, M. A.; Wernicke, B. P.; Farley K. A.; and Dumitru, T. A. 1997. Cenozoic thermal evolution of the central Sierra Nevada, California, from (U-Th)/He thermochronometry. Earth Planet. Sci. Lett. 151:167-179.

Jolivet, L., and J.-P. Brun. 2010. Cenozoic geodynamic evolution of the Aegean. Int. J. Earth Sci. 99:109-138.

Jolivet, L.; Daniel, J. M.; Truffert, C.; and Goffé, B. 1994. Exhumation of deep crustal metamorphic rocks and crustal extension in back-arc regions. Lithos 33:3-30.

Jolivet, L., and Faccenna, C. 2000. Mediterranean extension and the Africa-Eurasia collision. Tectonics 19: 1095-1106.

Jolivet, L.; Faccenna, C.; and Huet, B. 2012. Aegean tectonics: strain localisation, slab tearing and trench retreat. Tectonophysics 597-598:1-33.

Jolivet, L.; Famin, V.; Mehl, C.; Parra, T.; Aubourg, C.; Hébert, R.; and Philippot, P. 2004. Progressive strain localisation, boudinage and extensional metamorphic complexes, the Aegean Sea case. In Whitney, D. L.; Teyssier, C.; and Siddoway, C. S., eds. Gneiss domes in orogeny. Geol. Soc. Am. Spec. Pap. 380:185-210.

Jolivet, L.; Goffe, B.; Bousquet, R.; Oberhansli, R.; and Michard, A. 1998. Detachments in high-pressure mountain belts, Tethyan examples. Earth Planet. Sci. Lett. 160:31-47.

Jolivet, L.; Goffe, B.; Monie, P.; Truffert-Luxey, C.; Patriat, M.; and Bonneau, M. 1996. Miocene detachment in Crete and exhumation $P$-T-t paths of high pressure metamorphic rocks. Tectonics 15:1129-1153.

Kissel, C., and Laj, C. 1988. The tertiary geodynamical evolution of the Aegean arc: a paleomagnetic reconstruction. Tectonophysics 146:183-201.

Krahl, J.; Kauffmann, G.; Kozur, H.; Richter, D.; Forster, O.; and Heinritzi, F. 1983. Neue Daten zur Biostratigraphie and zur tectonischen Lagerun der Phyllit-
Gruppe und der Trypali-Gruppe auf der Insel Kreta (Griechenland). Geol. Rundsch. 72:1147-1166.

Lekkas, Sp. 1986. Les unités structurales dans l'île de Cythère. Bull. Geol. Soc. Greece 20:159-173.

Lister, G. S.; Banga, G.; and Feenstra, A. 1984. Metamorphic core complexes of Cordilleran type in the Cyclades. Aegean Sea, Greece. Geology 12:221-225.

Lister, G. S.; Forster, M. A.; and Rawling, T. J. 2001. Episodicity during orogenesis. In Miller, J. A.; Holdsworth, R. E.; Buick, I. S.; and Hand, M., eds. Continental reactivation and reworking. Geol. Soc. Lond. Spec. Publ. 184:89-113.

Lyberis, N.; Angelier, J.; and Barrier, E. 1982. Active deformation of a segment of arc: the strait of Kythira, Hellenic arc, Greece. J. Struct. Geol. 3:299-311.

Marsellos, A. E.; Foster, D. A.; Kamenov, G. D.; and Kyriakopoulos, K. G. 2012a. Detrital zircon U-Pb data from the Hellenic South Aegean belts: constraints on the age and source of the South Aegean basement. In Lister, G. S., and Skourtsos, E., eds. Geology of Greece. J. Virtual Exp. Spec. Ed. 42:3.

Marsellos, A. E., and Kidd, W. S. F. 2006. Detachment fault and shear zone of the Cretan-Peloponnese ridge in Kythera Island. Geol. Soc. Am. Abstr. Program 38: 238.

- 2008. Extension and exhumation of the Hellenic forearc ridge in Kythera. J. Geol. 116:640-651.

Marsellos, A. E.; Kidd, W. S. F.; and Garver, J. I. $2010 a$. Extension and exhumation of the HP/LT rocks in the Hellenic forearc ridge. Am. J. Sci. 310:1-36.

Marsellos A. E.; Kidd, W. S. F.; Garver, J. I.; and Kyriakopoulos, K. G. 2010b. Exhumation of the Hellenic accretionary prism: evidence from fission-track thermochronology. Hell. Geol. Soc. Greece 43:309-319.

- 2012b. Exhumation of HP-rocks accompanied by low-angle normal faulting and associated detachment fault of Milos Island: evidence from zircon fissiontrack thermochronology. Geochem. Mineral. Petrol. 49:49-64

Molnar, P., and Atwater, T. 1978. Inter-arc spreading and Cordilleran tectonics as alternates related to the age of the subducted lithosphere. Earth Planet. Sci. Lett. 41:330-340.

Montario, M. J.; Marsellos, A. E.; and Garver, J. I. 2008. Annealing of radiation damage in a Grenville zircon from the eastern Adirondacks, NY state. In Garver, J. I., and Montario, M. J., eds. Proceedings of the 11 th International Conference on Thermochronometry (Anchorage, AK, 2008), p. 174-176.

Murray, K. E.; Orme, D. A.; and Reiners, P. W. 2011. Apatite (U-Th)/He date dispersion due to secondary grain boundary phases: an example from the Henry Mountains, Utah. American Geophysical Union Fall Meeting 2011, abstract V23A-2556.

Pe-Piper, G. 1982. Geochemistry, tectonic setting and metamorphism of the mid-Triassic volcanic rocks of Greece. Tectonophysics 85:253-272.

Petrocheilos, J. 1966. Geological map of Kythera Island, scale $1: 50,000$. Athens, Institute for Geology and Subsurface Research. 
Platt, J. P. 1986. Dynamics of orogenic wedges and the uplift of high-pressure metamorphic rocks. Bull. Geol. Soc. Am. 97:1037-1053.

Postma, G.; Fortuin, A. R.; and Van Wamel, W. A. 1993. Basin-fill patterns controlled by tectonics and climate: the Neogene "fore-arc" basins of eastern Crete as a case history. Spec. Publ. Int. Assoc. Sediment. 20:335362.

Rahl, J. M.; Anderson, K. M.; Brandon, M. T.; and Fassoulas, C. 2005. Raman spectroscopic carbonaceous material thermometry of low-grade metamorphic rocks: calibration and application to tectonic exhumation in Crete, Greece. Earth Planet. Sci. Lett. 240: 339-354.

Ring, U.; Brachert, T.; and Fassoulas, C. 2001. Middle Miocene graben development in Crete and its possible relation to large-scale detachment faults in the southern Aegean. Terra Nova 13:297-304.

Robertson, A. H. F., and Dixon, J. E. 1984. Introduction: aspects of the geological evolution of the Eastern Mediterranean. In Dixon, J. E., and Robertson, A. H. F., eds. The geological evolution of the Eastern Mediterranean. Geol. Soc. Lond. Spec. Publ. 17:1-74.

Rosenbaum, G.; Lister, G. S.; and Duboz, C. 2004. The Mesozoic and Cenozoic motion of Adria (central Mediterranean): a review of constraints and limitations. Geodin. Acta 17:125-139.

Royden, L. H. 1993. Evolution of retreating subduction boundaries formed during continental collision. Tectonics 12:629-638.

Royden, L. H., and Husson, L. 2006. Trench motion, slab geometry and viscous stresses in subduction systems. Geophys. J. Int. 167:881-905. doi:10.1111/j.136546X.2006.03079.x.

Salaón, G.; Pedersen, H.; Paul, A.; Farra, V.; Karabulut, H.; Hatzfeld, D.; Papazachos, C.; Childs, D. M.; Pequegnat, C.; and the SIMBAAD Team. 2012. Highresolution surface wave tomography of the AegeanAnatolia region: constraints on upper mantle structure. Geophys. J. Int. 190:406-420.

Seidel, E.; Kreuzer, H.; and Harre, W. 1982. A Late Oligocene/Early Miocene high-pressure belt in the external Hellenides. Geol. Jahrb. E23:165-206.

Seidel, E.; Okrusch, M.; Kreuzer, H.; Raschka, H.; and Harre, W. 1976. Eo-alpine metamorphism in the uppermost unit of the Cretan nappe system-petrology and geochronology. I. The Lendas area (Asteroussia Mountains). Contrib. Mineral. Petrol. 57:259-275.

Shan, J.; Min, K.; and Nouiri, A. 2013. Thermal effects of scanning electron microscopy on He diffusion in apatite: implications to (U-Th)/He dating. Chem. Geol. 345:113-118.

Shuster, D. L.; Flowers, R. M.; and Farley, K. A. 2006. The influence of natural radiation damage on helium diffusion kinetics in apatite. Earth Planet. Sci. Lett. 249:148-161.

Spakman, W.; van der Lee, S.; and van der Hilst, R. 1993. Travel-time tomography of the European-Mediterranean mantle down to $1400 \mathrm{~km}$. Phys. Earth Planet. Inter. 79:3-74.
Spakman, W.; Wortel, M. J. R.; and Vlaar, N. J. 1988. The Hellenic subduction zone: a tomographic image and its geodynamic implications. Geophys. Res. Lett. 15: 60-63.

Spiegel, C.; Kohn, B.; Belton, D.; Berner, Z.; and Gleadow, A. 2009. Apatite (U-Th-Sm)/He thermochronology of rapidly cooled samples: the effect of He implantation. Earth Planet. Sci. Lett. 285:105-114.

ten Veen, J. H., and Kleinspehn, K. L. 2003. Incipient continental collision and plate-boundary curvature: Late Pliocene-Holocene transtensional Hellenic forearc, Crete, Greece. J. Geol. Soc. Lond. 160:161-181.

Theodoropoulos, D. K. 1973. Géographie physique de l'île de Cythère. Thesis, Université d'Athènes.

Theye, T., and Seidel, E. 1991. Petrology of low-grade high-pressure metapelites from the external Hellenides (Crete, Peloponnese): a case study with attention to sodic minerals. Eur. J. Mineral. 3:343-366.

- 1993. Uplift-related retrogression history of aragonite marbles in western Crete (Greece). Contrib. Mineral. Petrol. 114:349-356.

Theye, T.; Seidel, E.; and Vidal, O. 1992. Carpholite, sudoite, and chloritoid in low-grade high-pressure metapelites from Crete and the Peloponnese, Greece. Eur. J. Mineral. 4:487-507.

Thomson, S. N.; Stockhert, B.; and Brix, M. R. 1998. Thermochronology of the high-pressure metamorphic rocks of Crete, Greece: implications for the speed of tectonic processes. Geology 26:259-262.

- 1999. Miocene high-pressure metamorphic rocks of Crete: rapid exhumation by buoyant escape. In Ring, U.; Brandon, M.; Lister, G. S.; and Willet, S., eds. Exhumation processes: normal faulting, ductile flow and erosion. J. Geol. Soc. Lond. Spec. Publ. 154:87-107.

van Hinsbergen, D. J. J. 2010. A key extensional metamorphic complex reviewed and restored: the Menderes Massif of western Turkey. Earth Sci. Rev. 102: 60-76.

van Hinsbergen, D. J. J.; Hafkenscheid, E.; Spakman, W.; Meulenkamp, J. E.; and Wortel, M. J. R. 2005a. Nappe stacking resulting from subduction of oceanic and continental lithosphere below Greece. Geology 33: 325-328.

van Hinsbergen, D. J. J.; Langereis, C. G.; and Meulenkamp, J. E. 2005b. Revision of the timing, magnitude and distribution of Neogene rotations in the western Aegean region. Tectonophysics 396:1-34.

van Hinsbergen, D. J. J., and Schmid, S. M. 2012. Mapview restoration of Aegean-west Anatolian accretion and extension since the Eocene. Tectonics 31, TC5005. doi:10.1029/2012TC003132.

Vermeesch, P. 2010. HelioPlot, and the treatment of overdispersed (U-Th-Sm)/He data. Chem. Geol. 271:108111.

Vermeesch, P.; Seward, D.; Latkoczy, C.; Wipf, M.; Gunther, D.; and Baur, H. 2007. $\alpha$-emitting mineral inclusions in apatite, their effect on (U-Th)/He ages, and how to reduce it. Geochim. Cosmochim. Acta 71: 1737-1746.

Walcott, C. R., and White, S. H. 1998. Constraints on 
the kinematics of post-orogenic extension imposed by stretching lineations in the Aegean region. Tectonophysics 298:155-175.

Xypolias, P.; Dorr, W.; and Zulauf, G. 2006. Late Carboniferous plutonism within the pre-Alpine basement of the external Hellenides (Kithira, Greece): evidence from U-Pb zircon dating. J. Geol. Soc. Lond. 163:539_ 547.

Zulauf, G.; Romano, S. S.; Dorr, W.; and Fiala, J. 2007. Crete and the Minoan terranes: age constraints from $\mathrm{U}-\mathrm{Pb}$ dating of detrital zircons. Geol. Soc. Am. Spec. Pap. 423:401-411. 